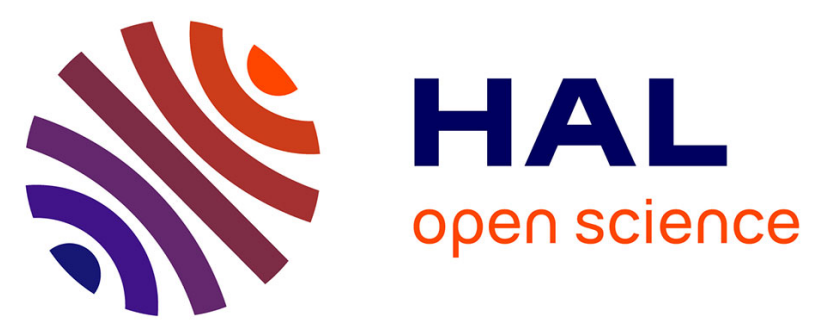

\title{
Quantifying the impacts of artisanal gold mining on a tropical river system using mercury isotopes
}

Sylvaine Goix, Laurence Maurice, Laure Laffont, Raphaelle Rinaldo, Christelle Lagane, Jérôme Chmeleff, Johanna Menges, Lars-Eric Heimbürger-Boavida, Régine Maury-Brachet, Jeroen E. Sonke

\section{To cite this version:}

Sylvaine Goix, Laurence Maurice, Laure Laffont, Raphaelle Rinaldo, Christelle Lagane, et al.. Quantifying the impacts of artisanal gold mining on a tropical river system using mercury isotopes. Chemosphere, 2019, 219, pp.684-694. 10.1016/j.chemosphere.2018.12.036 . hal-02107221

\section{HAL Id: hal-02107221 \\ https://hal.science/hal-02107221}

Submitted on 9 May 2019

HAL is a multi-disciplinary open access archive for the deposit and dissemination of scientific research documents, whether they are published or not. The documents may come from teaching and research institutions in France or abroad, or from public or private research centers.
L'archive ouverte pluridisciplinaire HAL, est destinée au dépôt et à la diffusion de documents scientifiques de niveau recherche, publiés ou non, émanant des établissements d'enseignement et de recherche français ou étrangers, des laboratoires publics ou privés. 


\title{
Quantifying the impacts of artisanal gold mining on a tropical river system using mercury isotopes
}

\author{
Sylvaine Goix ${ }^{\text {a, b }}$, Laurence Maurice ${ }^{a, *}$, Laure Laffont ${ }^{a}$, Raphaelle Rinaldo ${ }^{c}$, \\ Christelle Lagane ${ }^{a}$, Jerome Chmeleff ${ }^{a}$, Johanna Menges ${ }^{\mathrm{a}, \mathrm{e}}$, Lars-Eric Heimbürger ${ }^{\mathrm{a}, \mathrm{d}}$, \\ Régine Maury-Brachet ${ }^{\mathrm{f}}$, Jeroen E. Sonke ${ }^{\mathrm{a}}$ \\ a Géosciences Environnement Toulouse (GET), Observatoire Midi Pyrénées, CNRS, IRD, Université de Toulouse, 31400 Toulouse, France \\ ${ }^{\mathrm{b}}$ Institut Écocitoyen pour la Connaissance des Pollutions, Centre de Vie La Fossette RD 268, 13270 Fos-sur-Mer, France \\ c Parc Amazonien de Guyane, 1 rue Lederson, Remire-Montjoly, Guyane française, France \\ ${ }^{\mathrm{d}}$ Aix Marseille Université, CNRS/INSU, Université de Toulon, IRD, Mediterranean Institute of Oceanography (MIO) UM 110, 13288, Marseille, France \\ e GFZ German Research Centre for Geosciences, Section 5.1: Geomorphology, Potsdam, Germany \\ ${ }^{\mathrm{f}}$ University of Bordeaux, UMR EPOC 5805, Place du Dr Peyneau, 33120 Arcachon, France
}

\section{H I G H L I G H T S}

- Hg isotope ratios measured in soils and river sediments from French Guiana.

- Hg isotope ratios coupled to multiple linear regression to quantify anthropogenic Hg.

- Active ASGM activities increase THg in sediments by $78 \%$.

- Up to 70\% of anthropogenic $\mathrm{Hg}$ originates from liquid $\mathrm{Hg}$ used in ASGM.

\section{A R T I C L E I N F O}

\section{Article history:}

Received 24 August 2018

Received in revised form

30 November 2018

Accepted 5 December 2018

Available online 8 December 2018

Handling Editor: Martine Leermakers

\section{Keywords:}

Mercury stable isotopes

Mercury speciation

Artisanal and small-scale gold mining

(ASGM)

French Guiana
G R A P H I C A L A B S T R A C T

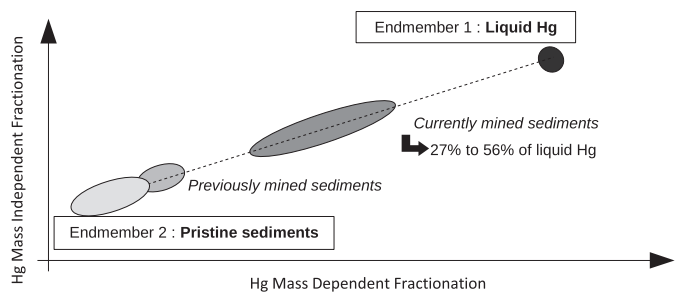

\section{A B S T R A C T}

In some locations, artisanal and small-scale gold-mining (ASGM) represents a significant source of anthropogenic $\mathrm{Hg}$ to freshwater environments. The $\mathrm{Hg}$ released from ASGM can contaminate aquatic fauna and pose health risks to downstream populations. Total $\mathrm{Hg}(\mathrm{THg})$ concentrations, speciation, and isotopic compositions were analyzed in water, suspended particulate matter, soil, and bottom sediment samples from pristine areas and in places of active and legacy gold mining along the Oyapock River (French Guiana) and its tributaries.

Mass-independent fractionation (MIF) of even $\mathrm{Hg}$ isotopes in top soils $\left(\Delta^{200} \mathrm{Hg}=-0.06 \pm 0.02 \%\right.$, $\mathrm{n}=10$ ) implied the uptake of gaseous $\mathrm{Hg}(0)$ by plants, rather than wet deposition, as the primary $\mathrm{Hg}$ source. Odd isotope MIF was lower in deep soils $\left(\Delta^{199} \mathrm{Hg}=-0.75 \pm 0.03 \%, \mathrm{n}=7\right)$ than in top soils $\left(\Delta^{199} \mathrm{Hg}=-0.55 \pm 0.15 \%, \mathrm{n}=3\right)$. This variation could be attributed to differences between the isotopic signatures of modern and pre-industrial atmospheric $\mathrm{Hg}$.

Combining a Hg-isotope binary mixing model with a multiple linear regression based on physicochemical parameters measured in the sediment samples, we determined that active mined creek sediments are contaminated by ASGM activities, with up to $78 \%$ of $\mathrm{THg}$ being anthropogenic. Of this anthropogenic $\mathrm{Hg}$, more than half $(66-74 \%)$ originates from liquid $\mathrm{Hg}(0)$ that is released during ASGM. The remaining anthropogenic $\mathrm{Hg}$ comes from the ASGM-driven erosion of $\mathrm{Hg}$-rich soils into the river. The

\footnotetext{
* Corresponding author.

E-mail address: laurence.maurice@ird.fr (L. Maurice).
} 
isotope signatures of anthropogenic $\mathrm{Hg}$ in bottom sediments were no longer traceable in formerly mined rivers and creeks.

(c) 2018 Elsevier Ltd. All rights reserved.

\section{Introduction}

Mercury $(\mathrm{Hg})$ is a globally distributed trace metal that can induce serious health effects on living organisms depending on the time of exposure, its concentration and speciation. This toxic metal is released to the environment by natural processes, such as volcanism or rock weathering, and by anthropogenic activities (Mason et al., 1994). Among these activities, artisanal and smallscale gold mining (ASGM) is the largest contributor to the atmosphere, with about 727 tons per year (UNEP, 2013) and reaches the inland freshwater $\mathrm{Hg}$ release with approximatively 880 tons/year (Obrist et al., 2018). In 2009, Telmer and Veiga estimated that artisanal and small scale gold mining released between 640 and 1350 tons of mercury per year into the environment, from which $350 \mathrm{Mg} \mathrm{yr}^{-1}$ were directly emitted to the atmosphere while the remainder $\left(650 \mathrm{Mg} \mathrm{yr}^{-1}\right)$ were released into the hydrosphere (rivers, lakes, soils, tailings).

French Guiana has been home to legal and illegal gold mining for more than 150 years. Gold miners are exploiting both alluvial and colluvial materials but also native gold yields. In 2005, the gold production came for a quarter from primary gold ores (for 4 extraction sites only) and three quarters from alluvial placer deposits (Laperche et al., 2014). Most of the gold deposits are epigenetic, sited in the proximity of major geological structures, and linked to low and medium metamorphic grade granitoidgreenstone belts (Voicu et al. 2001). The gold bearing extraction areas cover a total surface of almost $29,000 \mathrm{~km}^{2}$, distributed on two large bands parallel to the coast (Laperche et al., 2014), one from Camopi to the western border with Surinam.

Annually, an estimated between 5 and 20 tons of gold were produced illegally, while only 1-2 tons were officially declared (Legg et al., 2015; Deloitte Développement Durable, 2018). In 2017, 170 illegal ASGM sites were detected (Deloitte Développement Durable, 2018). Most of them were located close to official SGM but ASGM sites are typically informal, not geographically defined, nor necessarily long-lived.

Despite ratification of the Minamata Convention by France, $\mathrm{Hg}$ is still commonly used for gold amalgamation by artisanal and smallscale miners $(\sim 1.3 \mathrm{~kg} \mathrm{Hg}$ for the production of $1 \mathrm{~kg} \mathrm{Au}$; Lacerda, 2003). These activities impact approximately $1841 \mathrm{~km}$ of rivers in French Guiana according to the French forestry service (ONF) and $5840 \mathrm{~km}$ of rivers for the whole Guyana shield (Rahm et al., 2017). After the amalgamation process in ASGM activities, $12-40 \%$ of $\mathrm{Hg}$ is evaporated while $1-35 \%$ is discharged with tailings as liquid $\mathrm{Hg}$ to soils or river (Velásquez-López, 2010). Gold extraction also indirectly leads to $\mathrm{Hg}$ release into aquatic ecosystems through the erosion of naturally $\mathrm{Hg}$-rich tropical soils during soil washing and deforestation (Roulet et al., 1999; Maurice-Bourgoin et al., 2002; Adler Miserendino et al., 2017).

$\mathrm{Hg}$ derived from soil erosion reaches aquatic ecosystems mainly as inorganic $\mathrm{Hg}(\mathrm{II})$ adsorbed on fine particles (Maurice-Bourgoin et al., 2003), whereas $\mathrm{Hg}$ from ASGM is released as liquid elemental Hg (Schuster, 1991). During its transfer in lentic zones, floodplain or reservoir lakes, $\mathrm{Hg}(0)$ oxidizes to $\mathrm{Hg}(\mathrm{II})$ mainly through photochemical processes. $\mathrm{Hg}$ (II) is then susceptible to methylation by biotic (microbial methylation) and abiotic processes to form the neurotoxic organic species monomethyl mercury
(MeHg). Through assimilation of ingested food, fishes bioaccumulates MeHg along the aquatic trophic chains (Morel et al., 1998; Roulet et al., 2000). Consequently, indigenous populations inhabiting in gold mining areas, which traditionally rely on hunting and fishing, may be subjected to high MeHg exposures (MauriceBourgoin et al., 2000; Harada et al., 2001; Niane et al., 2015; Castilhos et al., 2015; Laffont et al., 2011).

$\mathrm{Hg}$ isotopes have recently been used to quantify anthropogenic inputs and understand $\mathrm{Hg}$ cycling in natural water systems (Perrot et al., 2010; Liu et al., 2011; Gray et al., 2013; Sherman and Blum, 2013; Yin et al., 2013; Wiederhold, 2015; Donovan et al., 2016; Schudel et al., 2018; Adler Miserendino et al., 2017). Mercury has seven natural stable isotopes and displays large variations in both mass dependent fractionation (MDF, $\delta^{202} \mathrm{Hg}$ ) and mass independent fractionation (MIF, $\Delta{ }^{199} \mathrm{Hg}, \Delta^{201} \mathrm{Hg}$ ) in the environment (Blum and Bergquist, 2007; Blum et al., 2014; Yin et al., 2014). Almost all kinetic reactions involving $\mathrm{Hg}$ induce MDF and many of them have been quantified by experimental studies (Blum et al., 2014). In contrast, MIF is observed in few processes and large MIF occurs primarily during photochemical reactions through the magnetic isotope effect (Bergquist and Blum, 2009). Consequently, Hg stable isotopes ratios can be used to differentiate mercury sources and to trace geochemical or biological processes (Schudel et al., 2018; Jiskra et al., 2017).

The aim of the present study was to trace and quantify the $\mathrm{Hg}$ contamination due to artisanal and small-scale gold mining on a tropical river system using mercury isotopes. The study area is located in the Oyapock River watershed, in French Guiana, still poorly investigated and characterized by both pristine and goldmining areas. We analyzed total $\mathrm{Hg}$ concentrations, speciation and isotopic compositions in soils, sediments, suspended matter and water samples (1) to characterize the cycling of $\mathrm{Hg}$ in a tropical environment from soils to sediments and (2) to characterize and quantify anthropogenic $\mathrm{Hg}$ inputs in sediments using two different models based on $\mathrm{Hg}$ isotopic composition and geochemical characteristics of sediments.

\section{Material and methods}

\subsection{Study area}

The study was conducted in the Oyapock River Basin, in French Guiana along the Brazilian border. The Oyapock River (Oyapock R.) originates in the Tumuk Humak Mountains and runs northward along the Brazilian border towards the Atlantic Ocean. The Oyapock $R$. is joined by the Camopi River (Camopi R.) at the village of Camopi. Together, the Oyapock R. and Camopi R. drain an area of $24630 \mathrm{~km}^{2}, 49 \%$ of which is located in French Guiana and $51 \%$ of which is located in Brazil (Hiez and Dubreuil, 1963). The Oyapock R. is characterized by annual floods, generally occurring between December and August, with a peak flow in May. The Oyapock R. can be divided in two stretches: one upstream of the confluence with the Camopi R., between Trois-Sauts and Camopi ("Oyapock R. upstream"), and one downstream of the confluence of the Camopi R. ("Oyapock R. downstream") (Fig. 1). The upstream reach has never been impacted by ASGM while the Camopi R. basin and the downstream Oyapock R. have areas of both active and historical 


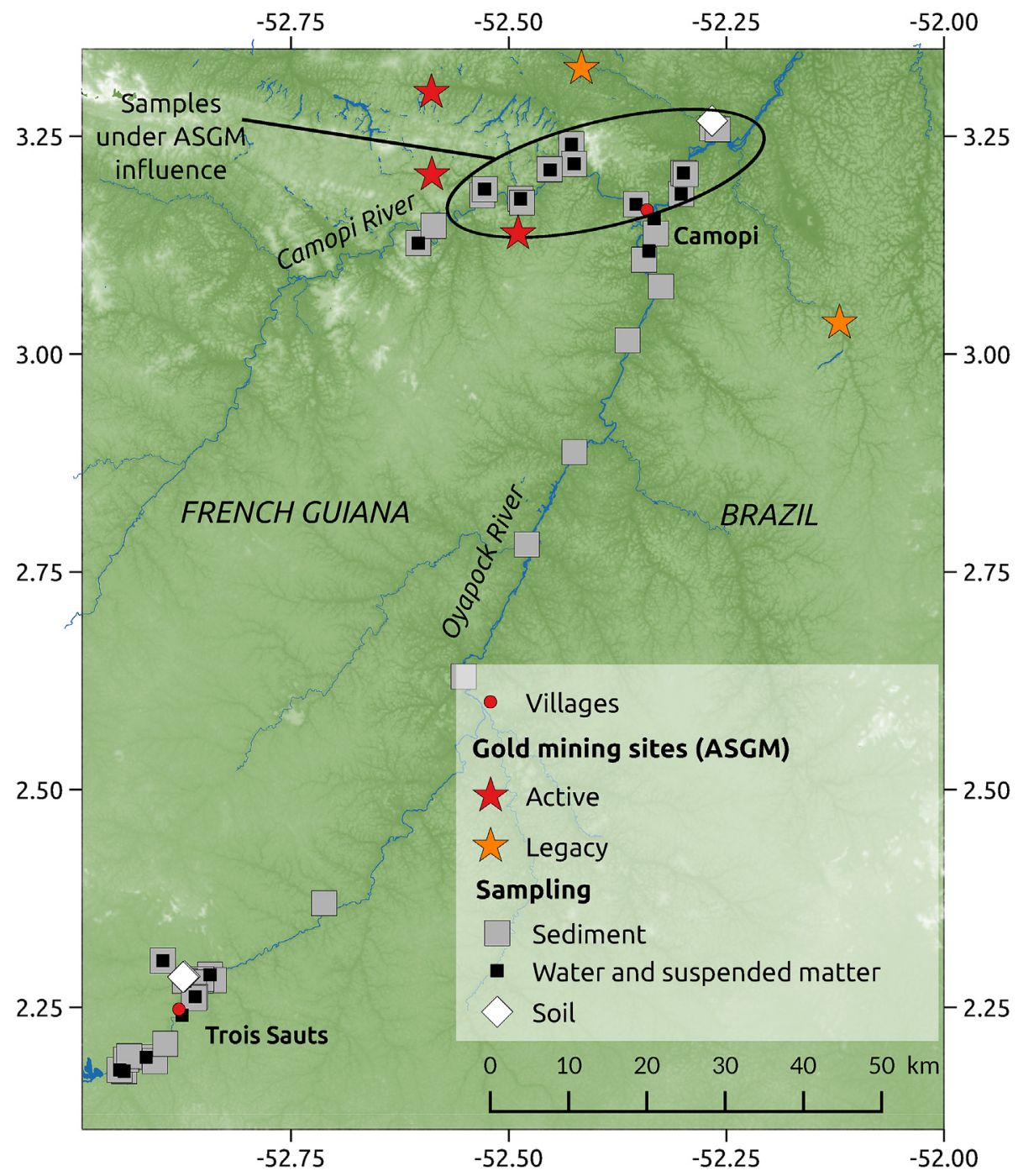

Fig. 1. Localization of sampling area.

ASGM activities. Upstream areas along both rivers were considered pristine, while their downstream regions were considered to be "mining areas".

The study area is located in the northern part of the Guiana Shield, which consists of igneous rocks (granite, gabbro and diorite) of Paleo-Proterozoic ages. According to the Caribbean Regional Climate Center, the average annual rainfall in Camopi is $2650 \mathrm{~mm}$. The mean annual temperature is $26.5^{\circ} \mathrm{C}$ and is relatively stable throughout the year. The study area is largely covered by dense tropical forests with high ecological biodiversity.

\subsection{Sampling}

Liquid mercury used in AGSM, bedrocks, topsoils and deep soils were collected in March 2010 throughout the Oyapock R. Basin. Surface water and bottom sediment samples in the pristine area were collected in October 2012, whereas the gold-mining area sampling took place in October 2013, both during the low water stage.

Bottom sediments were collected manually from flooded riverbanks with a custom sampler equipped with a clean HDPE flask. Sampling sites were chosen in areas where finer sediments tend to accumulate. Three types of sediments were sampled:
- 27 "pristine" sediments, in the Camopi and Oyapock rivers, upstream of known ASGM activities;

- 3 "active mining" sediments, in creeks with active ASGM;

- 9 "legacy mining” bottom sediments in the Oyapock and Camopi R. downstream with historical and active AGSM.

Leaves and twigs were manually removed from soil samples using clean gloves. Samples were immediately stored in sealed polyethylene bags and frozen at $-18^{\circ} \mathrm{C}$. Subsequently, samples were dried in a vertical laminar air flow hood at room temperature. Sediments were dry-sieved using a $2 \mathrm{~mm}$ nylon mesh to remove remaining fragments of organic matter (OM). Samples were then finely crushed in an agate mortar after grain size analysis (by laser diffraction).

Surface water was sampled at selected sediments sampling sites $(\mathrm{n}=19)$. Among the samples, 11 were located in pristine areas, 3 in active mining areas and 5 in historical mining areas. Surface water samples were collected manually, in 2L Teflon (FEP) bottles. The bottles were previously cleaned in the laboratory with $\mathrm{HCl} 50 \%$ at $120^{\circ} \mathrm{C}$ over $12 \mathrm{~h}$, rinsed with ultrapure water, then stored with a small volume of bi-distilled $\mathrm{HCl}$ diluted with ultrapure water $(10 \%$ $\mathrm{v} / \mathrm{v}$ ) until sampling. Each bottle was rinsed 3 times with the river surface water at each sampling point and filled $20 \mathrm{~cm}$ below the 
water surface. The samples were filtered between 1 and $6 \mathrm{~h}$ after sampling in situ using clean quartz membranes (Whatman ${ }^{\circledR}, 0.7 \mu \mathrm{m}$ porosity, calcined at $550^{\circ} \mathrm{C}$ ) in a clean filtration unit (polysulphone Nalgene ${ }^{\circledR}$ filtration system, cleaned with $\mathrm{HCl} 50 \%, 12 \mathrm{~h}$, rinsed with ultrapure water) and transferred into clean bottles for analysis. The volume of water filtered was weighted in the field. The weight obtained was converted to volume assuming a density of 1 typical of clear freshwater. Water samples were stored in clean Teflon bottles for $\mathrm{Hg}$ analysis (acidified with bi-distilled $\mathrm{HCl} 0.4 \% \mathrm{v} / \mathrm{v}$ ) and glass vials (calcined at $550^{\circ} \mathrm{C}$ ) for carbon analysis (acidified with $\mathrm{H}_{3} \mathrm{PO}_{4} 0.4 \% \mathrm{v} / \mathrm{v}$ ). Filters were frozen at $-20^{\circ} \mathrm{C}$ in aluminum and clean plastic Petrislides for $\mathrm{C}$ and $\mathrm{Hg}$ analyses respectively, while filtered water samples were kept at $4{ }^{\circ} \mathrm{C}$ after acidification.

Soil samples were collected along small tributaries of the Oyapock R., and in the Sikini and Ipoussin Creeks which are respectively located near Camopi and Trois-Sauts (Fig. 1). Topsoils and deep soils were sampled from natural outcrops on river banks. Topsoils were collected from the forest floor; the two first centimeters of litter and root mat were cleaned. Deep soil samples were collected on the stream banks and downslope from the catchment area, at least $2-3 \mathrm{~m}$ above the water level, after removal of the superficial layer in direct contact with the atmosphere, provided access to deep soil horizons (from 0.5 to $3 \mathrm{~m}$ depth). On each profile, three main horizons were sampled: i) reddish brown topsoil, ii) red compact horizon and iii) yellowish-brown horizon. The topsoil sample located in the Ipoussin creek in the Trois-Sauts area was identified as a sandy-loamy surface soil while the lowest horizons were all hydromorphics. Two topsoils were sampled in the Camopi watershed, and the deep horizons were identified as ultisols. The soil profile from Camopi area was considered as uncontaminated given the distance of $\sim 20 \mathrm{~km}$ from sampling site to the closest known mining site. Contaminated soils near AGSM were not sampled given the danger to access these sites. As deep soils were sampled on the river bank, they were possibly submitted to physicochemical process due to their proximity with air and water. Nevertheless, they were more representative of the soil's particle input to rivers than preserved soils would have been. All soil samples were kept frozen in the field and then freeze-dried before analysis of total $\mathrm{Hg}$ concentrations and isotopic compositions.

Three bedrock samples from the Guiana shield were collected in the Oyapock R., $1 \mathrm{~km}$ upstream of its confluence with the Camopi R. These bedrock samples were washed, crushed and ground before THg analyses.

Several milliliters of liquid mercury were collected by the French army from an active ASGM site in the Oyapock River basin, in March 2010. This liquid mercury was stored in a plastic vial isolated from the environmental samples.

\subsection{Physico-chemical analysis}

Grain-size distributions of the $<2 \mathrm{~mm}$ fraction of sediment were measured in ultrapure water by light scattering using a LA-960V2 Laser Particle Size Analyzer from Horiba ${ }^{\mathbb{R}}$. Samples were dispersed with sodium hexametaphosphate $(100 \mathrm{~g} / \mathrm{L})$ before ultrasonication (2-4 min). Ultrasonication was applied in 1-min steps until stable cumulative curves were obtained. Each sample was measured in triplicate.

Total $\mathrm{Hg}$ concentrations ([THg]) in soils, sediments, bedrocks and suspended matter were determined by flameless atomic absorption spectrometry using an AMA $254\left({ }^{(\mathbb{R}}\right.$ Leco-France, details are given in supplementary material). Three different CRMs were used for bulk sediments, suspended matter and soils $\mathrm{THg}$ analysis to assess recovery and yielded $109 \%, 101 \%$ and $100 \%$ respectively. Each soil and sediment sample was measured at least in duplicate until obtaining a relative uncertainty less than $5 \%(1 \sigma)$.
Total dissolved $\mathrm{Hg}$ concentrations in waters were measured at the GET laboratory (Toulouse, France) on $35 \mathrm{~mL}$ aliquots by single gold trap coupled to a cold vapour atomic fluorescence spectrometer (CV-AFS Brooks Rand ${ }^{\circledR}$ Model III, USA) following the USEPA 1631 method (US EPA, 2002), modified for low-level measurements (Heimbürger et al., 2015, cf supplementary material). NRCC ORMS5 (Elevated Mercury in River Water) was used to assess recovery, and yielded a value of $98 \pm 9 \%(n=14)$.

$\mathrm{MeHg}$ and inorganic $\mathrm{Hg}$ ( $\mathrm{IHg}$ ) concentrations in sediments were determined by double-spiking species-specific isotope dilution using a gas chromatograph (Thermo) coupled to a sector field ICPMS (Thermo Element-XR) at the GET laboratory (ID-GC-SF-ICP-MS). $\mathrm{MeHg}$ and $\mathrm{IHg}$ were soft extracted by open-focused micro-wave $\left({ }^{\circledR} \mathrm{CEM}\right.$ Discover $)$ in $6 \mathrm{~N} \mathrm{HNO}_{3}$, then derivatizated following previously published protocols (Heimbürger et al., 2015; Monperrus et al., 2008; Martın-Doimeadios et al., 2004); these procedures are fully described in Supplementary material. The MeHg concentrations in the reference material IAEA-405 displayed a recovery of $89 \%$ and a reproducibility of $3 \%(1 \mathrm{~s}, \mathrm{n}=3)$.

Sample preparation for $\mathrm{Hg}$ stable isotope analysis is detailed in the supplementary material. Mercury stable isotope ratios were measured in sediments and soils by continuous flow cold vapour generation (using $\mathrm{Sn}(\mathrm{II})$ reduction) multi-collector inductively coupled plasma mass spectrometry (CV-MC-ICP-MS, Thermo Finnigan $^{\circledR}$ Neptune, Germany) at the GET laboratory according to previously published method (Enrico et al., 2016; Masbou et al., 2015). Instrumental mass bias was corrected by sample-standard bracketing using NIST SRM 3133 at matching concentrations. Hg isotopic compositions are reported as $\delta$-values, expressed in permil $(\%)$, which permit (Equation (1)) deviation of the isotopic ratio measured in a sample from the bracketing standard:

$\delta^{X X X} H g=\left(\frac{\left(\frac{{ }^{X X X} H g}{{ }^{198} H g}\right)_{\text {sample }}}{\left(\frac{X X X}{19 g}\right)_{\text {SRM3133 }}}-1\right) * 1000$

MIF was quantified using the equation (2), as the $\delta$-value deviation from the theoretical MDF:

$\Delta^{\mathrm{XXX}} H g=\delta^{\mathrm{XXX}} H g_{\text {sample }}-\beta * \delta^{202} H g_{\text {sample }}$

where $\beta$-values for ${ }^{199} \mathrm{Hg},{ }^{200} \mathrm{Hg},{ }^{201} \mathrm{Hg}$ and ${ }^{204} \mathrm{Hg}$ are $0.252,0.502$, 0.752 , and 1.493 respectively according to the kinetic MDF law (Blum and Bergquist, 2007). Long-term reproducibility of $\mathrm{Hg}$ isotopes measurements was assessed by analyzing UM-Almaden $(\mathrm{n}=5)$, ETH-Fluka $(\mathrm{n}=10)$ and the procedural standards MESS-3 $(\mathrm{n}=8)$ and SJS $2709(\mathrm{n}=2)$ (SI Table S1). The uncertainty on $\mathrm{Hg}$ stable isotope compositions of environmental samples was calculated as 2SD on sample replicates except if they were lower than MESS-3 reproducibility (2SD).

\subsection{Statistical analysis}

Statistical analyses were done using $\odot \mathrm{R}$ (Version 3.4.4). Comparison tests were conducted with both Wilcoxon (medians) and $t$ test (mean). Two samples $t$-test were used when data showed a normal distribution (Shapiro test) and homoscedasticity (F Test). In other cases, and especially when sample size was low, the Wilcoxon test was applied. A confidence level of 0.95 was chosen. Means or medians were considered to be significantly different when the pvalue was less than 0.05 . Multiple linear regressions were performed with the lm function (package base), using all geochemical parameters as explanatory variables to understand the $\mathrm{Hg}$ concentrations observed in uncontaminated sediments. Explanatory 
variables with p-values inferior to 0.05 were removed from the model after a stepwise selection based on Akaïke Information Criterion. Residual analysis and regression diagnosis were performed to ensure the reliability of the model.

\section{Results and discussion}

Results of [THg], [MeHg], $\mathrm{Hg}$ isotopic composition and main physicochemical parameters of all samples are summarized in Tables S3, S4 and S5 in Supplementary material for sediment, soil and water samples, respectively.

\subsection{Mercury concentrations, isotopic composition and speciation in} rocks, soils, water, sediments and liquid $\mathrm{Hg}$

\subsection{1. $\mathrm{Hg}$ in bedrock and soils}

[THg] in bedrocks of the Oyapock R. basin ranged from 1.6 to $2.9 \mathrm{ng} \mathrm{g}^{-1}$ with an average of $2.1 \pm 0.7 \mathrm{ng} \mathrm{g}^{-1}(\mathrm{n}=3)$. These low concentrations agree with bedrocks sampled in French Guiana ranging from 3 to $7 \mathrm{ng} \mathrm{g}^{-1}$ (Grimaldi et al., 2001). [THg] in topsoils ranged from 29 to $81 \mathrm{ng} \mathrm{g}^{-1}$ with an average of $47 \pm 29 \mathrm{ng} \mathrm{g}^{-1}$ $(n=3)$; the highest value was found in the Trois Sauts area. [THg] in deep soil horizons ranged from 48 to $100 \mathrm{ng} \mathrm{g}^{-1}$ with an average of $68 \pm 19 \mathrm{ng} \mathrm{g}^{-1}(n=7)$. These concentrations were in the range of concentrations reported in ultisols and hydromorphic soils of the Amazonian region (Roulet and Grimaldi, 2001).

The topsoil sampled in the Camopi area had less negative MIF and MDF (respectively $\Delta^{199} \mathrm{Hg}=-0.38 \pm 0.06 \%$ and $\delta^{202} \mathrm{Hg}=-0.94 \pm 0.10 \%$ ) than the two topsoils from the Trois-Sauts area (respectively $\quad \Delta{ }^{199} \mathrm{Hg}=-0.64 \pm 0.04 \%$ and $\delta^{202} \mathrm{Hg}=-1.76 \pm 0.10 \%$ ). Deep soil horizons had more negative odd MIF $\left(\Delta^{199} \mathrm{Hg}=-0.75 \pm 0.03 \%, \quad \mathrm{n}=7\right)$ and MDF $\left(\delta^{202} \mathrm{Hg}=-2.21 \pm 0.14 \%\right.$ ) than topsoils $(\mathrm{p}=0.016)$. Even MIF in deep soil horizons $\left(\Delta^{200} \mathrm{Hg}=-0.06 \pm 0.02 \%, \mathrm{n}=7\right.$ ) was similar $(\mathrm{p}=0.57)$ to that of topsoils and statistically different from $0(\mathrm{p}=0.022)$.

There were no significant differences in [THg], odd MIF or MDF in deep soil horizons between samples from Camopi $(n=3)$ and Trois-Sauts $(\mathrm{n}=4)$ (respectively $\mathrm{p}=0.4, \mathrm{p}=0.06$ and $\mathrm{p}=0.86$ ). A linear relation between MIF and MDF was observed in soil samples (Fig. 2).

\subsection{2. $\mathrm{THg}$ in surface waters}

Total dissolved mercury concentrations $[\mathrm{THg}]$ in water $\left([\mathrm{THg}]_{\mathrm{D}}\right)$ ranged from 0.34 to $1.03 \mathrm{ng} \mathrm{L}^{-1}$, with an average of
$0.70 \pm 0.21 \mathrm{ng} \cdot \mathrm{L}^{-1}(\mathrm{n}=16)$ and were significantly higher $(\mathrm{p}=0.02)$ in mining areas $\left(0.84 \pm 0.16 \mathrm{ng} . \mathrm{L}^{-1}, \mathrm{n}=6\right)$ than in pristine areas $\left(0.61 \pm 0.18 \mathrm{ng} . \mathrm{L}^{-1}, \mathrm{n}=10\right)$. Higher levels of $[\mathrm{THg}]_{\mathrm{D}}$ were previously observed in the mining-impacted watershed of Combat Creek in French Guiana by Guedron et al. (2006), averaging 0.98 ng.L L $^{-1}$ and 4.94 ng. $\mathrm{L}^{-1}$ in pristine and mined areas, respectively.

Total particulate $\mathrm{Hg}$ concentrations $[\mathrm{THg}]$ in water $\left([\mathrm{THg}]_{\mathrm{P}}\right)$ ranged from 1.7 to $17.3 \mathrm{ng} . \mathrm{L}^{-1}$ with an average of $4.0 \pm 4.5 \mathrm{ng} . \mathrm{L}^{-1}$ $(\mathrm{n}=11)$ and were significantly higher $\left(\mathrm{p}=4.10^{-5}\right)$ in mined areas $\left(4.6 \pm 5.2 \mathrm{ng} . \mathrm{L}^{-1}, \mathrm{n}=8\right)$ than in pristine areas $\left(2.2 \pm 0.3 \mathrm{ng} . \mathrm{L}^{-1}\right.$ $\mathrm{n}=3)$.

\subsection{3. $\mathrm{Hg}$ in sediments}

Total mercury concentrations in bulk sediments ([THg $]_{\text {sed }}$ ) ranged from 32 to $358 \mathrm{ng} \mathrm{g}^{-1}$. The average concentration was significantly higher $(\mathrm{p}=0.024)$ in active ASGM areas $\left(150 \pm 88 \mathrm{ng} \mathrm{g}^{-1}, \mathrm{n}=12\right.$ ) than in pristine area (and $95 \pm 45 \mathrm{ng} \mathrm{g}^{-1}$, $\mathrm{n}=27$ ). This is consistent with previously measured [THg] in bottom sediments of the Oyapock and Camopi river basins (Laperche et al., 2014). The authors reported low [THg] in streams with clear to clouded water $\left(<150 \mathrm{ng} \mathrm{g}^{-1}\right)$ and high [THg] in turbid streams, which were indicative of recent gold-mining activity (200-800 $\mathrm{ng} \mathrm{g}^{-1}$ ). They also observed that [ $\mathrm{THg}$ ] in sediments from upstream areas of the Oyapock R. were always lower than $130 \mathrm{ng} \mathrm{g}^{-1}$

In all sediment samples from the present study, $\delta^{202} \mathrm{Hg}$ ranged from -2.52 to $-1.29 \%$. $\delta^{202} \mathrm{Hg}$ was significantly more negative $\left(\mathrm{p}=4.10^{-5}\right)$ in the pristine area $(-2.27 \pm 0.09 \%)$ than in the mining area $(-1.95 \pm 0.29 \%$ ) but lighter than values reported in the Puyango-Tumbes River system ranging from -0.27 to $-0.71 \%$ (Schudel et al., 2018) or than $-0.83 \%$ measured in the Dashuixi River in the Wanshan mercury mining area, in China (Yin et al., 2013). $\Delta^{199} \mathrm{Hg}$ in sediment samples ranged from -0.76 to $-0.3 \%$ o with an average of $-0.63 \pm 0.08 \%$. $\Delta{ }^{199} \mathrm{Hg}$ was also significantly more negative in the pristine area $(-0.66 \pm 0.04 \%)$ than in the mining area $(-0.56 \pm 0.11 \%, \mathrm{p}=0.0002$, Fig. 2$)$. MeHg concentrations were $<1.5 \%$ of $[\mathrm{THg}]_{\text {sed }}$ for all bulk sediments.

The percentages of the clay fraction $(<4 \mu \mathrm{m})$ measured by laser granulometry in study sediment samples were generally low and varied between 3 and 19\%, whereas the silt fraction (between 4 and $64 \mu \mathrm{m}$ ) varied between 18 and $82 \%$.

\subsubsection{Isotopic composition of liquid $\mathrm{Hg}$}

The $\mathrm{Hg}$ isotopic composition of the liquid $\mathrm{Hg}$ used by miners in the Oyapock R. basin showed no $\operatorname{MIF}\left(\Delta^{199} \mathrm{Hg}=-0.03 \pm 0.04 \%\right.$,

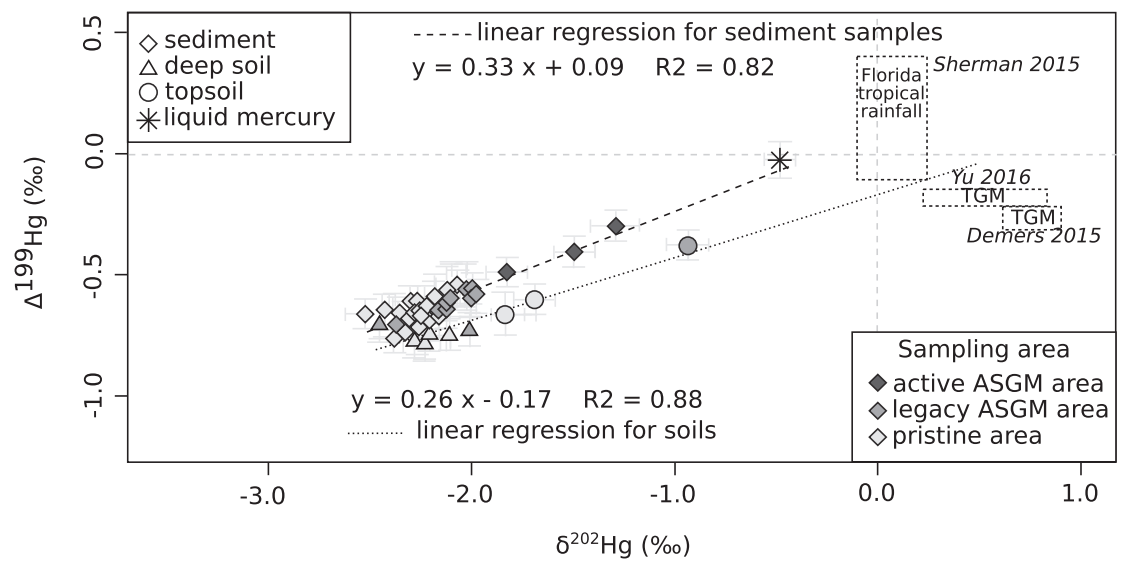

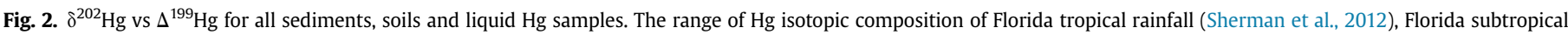
TGM (Demers et al., 2015) and China remote subtropical TGM (Yu et al., 2016) were reported. Error bars represent analytical 2SD. 
$\mathrm{n}=5)$ and a negative $\operatorname{MDF}\left(\delta^{202} \mathrm{Hg}=-0.48 \pm 0.08\right)$. This liquid $\mathrm{Hg}$ results match well with previous data of 2 samples of liquid $\mathrm{Hg}$ used by gold miners in Bolivia, with respectively $\delta^{202} \mathrm{Hg}=-0.37 \pm 0.09 \%$ and $-0.51 \pm 0.09 \%$ and $\Delta{ }^{199} \mathrm{Hg}=-0.05 \pm 0.03 \%$ and $0.03 \pm 0.03 \%$ (Laffont et al., 2011).

\subsection{Origin and cycle of non-anthropogenic $\mathrm{Hg}$ in tropical environment}

\subsubsection{Origin of $\mathrm{Hg}$ in topsoils}

Topsoil represents an interface between deeper soils and the atmosphere. Mercury in topsoils is influenced by: i) wet and dry $\mathrm{Hg}$ deposition as well as $\mathrm{Hg}$ input via litter deposition (Jiskra et al., 2015; Roulet and Grimaldi, 2001), ii) losses via Hg mobilization to deeper soil layers, and iii) $\mathrm{Hg}$ reduction and evasion to the atmosphere. The lithogenic fraction of $\mathrm{Hg}$ in Amazonian soils was previously shown to be negligible in surface soil layers (Guedron et al., 2006) as a consequence of the very low THg concentrations in the parent bedrock $\left(2.1 \mathrm{ng} \mathrm{g}^{-1}\right)$. In forested areas of the Amazon region, $\mathrm{Hg}^{0}$ emitted from mining sites to the atmosphere is deposited within 10-20 km from the source (Lacerda and Salomons, 2012). Consequently, deposition from mining operations $\left(\mathrm{Hg}^{0}(\mathrm{~g})\right.$ or $\mathrm{Hg}^{\mathrm{II}}$ resulting from $\mathrm{Hg}^{0}(\mathrm{~g})$ oxidation) should be negligible at both soil sites, located more than $20 \mathrm{~km}$ from the nearest known, known ASGM site. The low [THg] in the topsoils from the Camopi R. Basin suggests that it is unlikely that a recent $\mathrm{Hg}$ contamination occurred at this site.

Atmospheric $\mathrm{Hg}$ (wet, dry or gaseous) was not sampled in the present study, however, data on the origins of $\mathrm{Hg}$ in tropical and subtropical topsoils are available in the literature (Yu et al., 2016; Demers et al., 2015; Sherman et al., 2012). As shown by the MDF and MIF distributions in tropical rainfall and TGM (Fig. 2) $\mathrm{Hg}$ sources in litter horizons originate from both wet and gaseous $\mathrm{Hg}$ deposition and as proposed recently by Zheng et al. (2016), additional deposition of atmospheric $\mathrm{Hg}(0)$ may occur during litter decomposition. Even MIF could help to discriminate the source of atmospheric $\mathrm{Hg}$ in topsoils. Indeed, slightly negative $\Delta^{200} \mathrm{Hg}$ in ambient gaseous $\mathrm{Hg}$ have been opposed to positive $\Delta^{200} \mathrm{Hg}$ found in wet precipitation and attributed to photo-oxidation of $\mathrm{Hg}(0)$ to $\mathrm{Hg}$ (II) (Chen et al., 2012). Recent $\mathrm{Hg}$ isotope studies of terrestrial ecosystems have shown that vegetation and organic soil horizons have negative $\Delta^{200} \mathrm{Hg}$ and $\Delta^{199} \mathrm{Hg}$ that are more similar to atmospheric $\left(\mathrm{Hg}^{0}(\mathrm{~g})\right)$ than to $\mathrm{Hg}(\mathrm{II})$ in rainfall which has positive MIF (Demers et al., 2013; Enrico et al., 2016; Jiskra et al., 2015; Zheng et al., 2016). Negative even and odd MIF has been attributed to the uptake of gaseous $\mathrm{Hg}$ by plants. In our samples, the significantly negative $\left(\mathrm{p}=2.10^{-6}\right) \quad \Delta^{200} \mathrm{Hg} \quad$ signature of the soils $\left(\Delta^{200} \mathrm{Hg}=-0.06 \pm 0.02 \%, \mathrm{n}=10\right)$ is more similar to negative $\Delta^{200} \mathrm{Hg}$ of subtropical TGM in China (Yu et al., 2016) $\left(\Delta^{200} \mathrm{Hg}=-0.07 \pm 0.02 \%, \mathrm{n}=6\right)$ and from Florida (Demers et al., 2015) $\left(\Delta^{200} \mathrm{Hg}=-0.083 \pm 0.04 \%, \mathrm{n}=4\right)$ than to positive $\Delta^{200} \mathrm{Hg}$ of subtropical wet precipitation from Florida (Sherman et al., 2012) $\left(\Delta^{200} \mathrm{Hg}=0.14 \pm 0.07 \%\right.$ )

$\mathrm{Hg}^{0}(\mathrm{~g})$ is the main component of TGM in the tropical forests of French Guiana (Amouroux et al., 1999). Using an average $\delta^{202} \mathrm{Hg}$ of subtropical TGM litterature data (Demers et al., 2015; Yu et al., 2016), we observed an offset between TGM of subtropical environments and corresponding organic-rich topsoils of approximately $-1.0 \%$ o $(-1.5$ to $-2.5 \%$ ). This shift is in the same range as that observed between atmospheric $\mathrm{Hg}_{(\mathrm{g})}{ }_{(\mathrm{g})}$ and litter $\left(\delta^{202} \mathrm{Hg}\right.$ of -2 to $-3 \%$ ) which was attributed to light isotope enrichment during foliar uptake (Demers et al., 2013; Enrico et al., 2016; Jiskra et al., 2015; Yu et al., 2016).

Therefore, we suggest that, like in previous study in temperate environment (Zhang et al., 2013), Hg in tropical topsoils preferentially originates from $\mathrm{Hg}(0)_{\mathrm{g}}$ uptake by plants rather than from $\mathrm{Hg}$ (II) wet deposition, despite the high precipitation in the tropical environment. This is in accordance with recent observations at several sites in north America that show soils from sites subjected to high precipitation receive a higher proportion of $\mathrm{Hg}(0)$ deposition and a lower proportion of $\mathrm{Hg}$ (II) deposition than in the drier sites (Zheng et al., 2016). This was attributed to higher plant productivity and litterfall at wetter sites or to enhanced photochemical re-emission of newly deposited $\mathrm{Hg}$ (II) in wet deposition.

\subsubsection{Origin of $\mathrm{Hg}$ in deep soil horizons}

Measured [THg] in deep soils were at the lower end of previously reported [ $\mathrm{THg}]$ for forested soils in the Brazilian Amazon (Roulet and Grimaldi, 2001). Roulet et al. (1998b, 1998a) showed that [THg] of Amazonian soils decreased along a toposequence, from upslope to downslope and suggested that it was a result of intense leaching of clayey particles and aggregated oxy-hydroxide minerals, controlled by the topography and the resulting oblique drainage. The slope for the $\Delta^{199} \mathrm{Hg}: \Delta^{201} \mathrm{Hg}$ regression in all soil samples is $1.12 \pm 0.04\left(R^{2}=0.99, p=2.762 .10^{-09}\right.$, Fig. 3). This slope close to 1.0 is similar to the slope observed in N-American soils $(1.10 \pm 0.04,2 S E, n=75$; Zheng et al., 2016), and has been associated with the photoreduction of inorganic $\mathrm{Hg}$ (II) (Bergquist and Blum, 2009, 2007; Sonke, 2011). This MIF $_{\text {odd }}$ induced by aqueous photochemical processes in the river water or atmosphere water is transferred to soils by $\mathrm{Hg}$ deposition. The decrease of MIF $(-0.1$ to $-0.2 \%$ ) in deep soils compared to topsoils (Fig. 3 ) has already

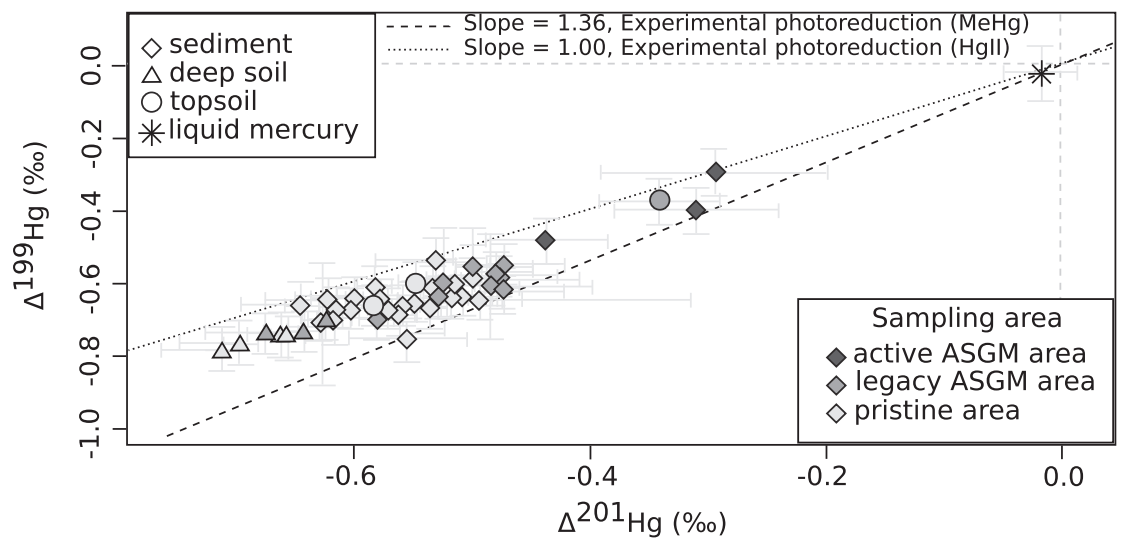

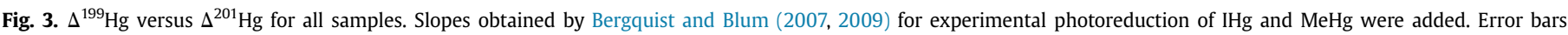
represent analytical $2 \mathrm{SD}$. 
been observed in U.S. by Zheng et al. (2016) but cannot be explained only by $\mathrm{Hg}$ deposition in forested soils (litterfall, atmospheric $\mathrm{Hg}(\mathrm{ox})$ ) nor reductive $\mathrm{Hg}$ losses. This variation of MIF cannot be modeled by a simple mix between exogenous and lithogenic $\mathrm{Hg}$. We have not analyzed the $\mathrm{Hg}$ isotopic composition of the parent bedrock in the present study. Indeed, lithogenic $\mathrm{Hg}$ in the studied deep horizons was considered as negligible given the very low [THg] of the parent bedrocks $\left(<3 \mathrm{ng} \mathrm{g}^{-1}\right)$. Furthermore, the $\mathrm{Hg}$ isotopic composition of volcanic and metamorphic rocks derived from Blum et al. (2014) $\left(\delta^{202} \mathrm{Hg}=0.76 \pm 0.48 \%\right.$, $\Delta^{199} \mathrm{Hg}=0.02 \pm 0.08 \%$ ) excludes the bedrocks as a possible end member for a deep soils mixing model between the isotopic compositions of theoretical litter and parent rock (Fig. 2). As mentioned, Zheng et al. (2016) observed a weak decrease in $\Delta^{199} \mathrm{Hg}(-0.08 \%$ ) with increasing age of organic horizons in peat soils. The observed isotopic depth profile in litter by Jiskra et al. (2015) was interpreted to reflect non photochemical reduction of $\mathrm{Hg}$ (II) by natural organic matter. Dark abiotic reduction of $\mathrm{Hg}$ (II) by organic matter also produces small negative $\mathrm{MIF}_{\text {odd }}$ in the residual $\mathrm{Hg}$ (II) (Zheng and Hintelmann, 2010), which could contribute to the small decrease of $\Delta^{199} \mathrm{Hg}$ along the organic soil profile. As the $\mathrm{MIF}_{\text {odd }}$ gradient observed in the French Guiana soils is higher than this previously reported by Zheng et al. (2016) and Jiskra et al. (2015), we suggest that the $\Delta^{199} \mathrm{Hg}$ in deep soils, which is more negative than the $\Delta{ }^{199} \mathrm{Hg}$ of topsoils in both soil profiles, can reflect the strongly negative $\Delta{ }^{199} \mathrm{Hg}$ of pre-anthropogenic atmospheric $\mathrm{Hg}$ deposited on soils or vegetation. Indeed, these tropical soils have accumulated $\mathrm{Hg}$ for several thousands of years (Roulet and Grimaldi, 2001) and the pre-anthropogenic atmospheric $\mathrm{Hg}(0)$ isotope composition was recently suggested to display a more negative $\Delta^{199} \mathrm{Hg}(-0.3$ to $-0.6 \%$ ) than modern $\mathrm{Hg}(0)$ in peat bog samples (Enrico et al., 2017).

\subsubsection{Origin and fate of $\mathrm{Hg}$ in sediments}

The negative MIF observed in sediments from the pristine area $\left(\Delta^{199} \mathrm{Hg}=-0.66 \pm 0.04 \%\right.$ ) is, to our knowledge, the most negative MIF ever measured in river sediments, also negative MIF was also recently observed in sediments from Ecuador (Schudel et al., 2018). Sediments in freshwater from the Amazonian basin derive directly from the inflow of particles from the catchment due to soil weathering and subsequent erosion (Maurice, 2001). A slight but significant $(p=0.0002)$ shift of $+0.09 \%$ in $\Delta^{199} \mathrm{Hg}$ is observed between deeper soil horizons from river bank outcrops and pristine sediments. Photochemical aquatic reduction is able to cause the observed shift, with the remaining $\mathrm{Hg}(\mathrm{II})$ in sediment having less negative $\Delta^{199} \mathrm{Hg}$ than the mobile $\mathrm{Hg}(0)$ produced. Correlation between $[\mathrm{THg}]_{\text {sed }}$ in all sediments with the percentage of clay fraction $(<4 \mu \mathrm{m})$ is weak $\left(\mathrm{R}^{2}=0.08, \mathrm{p}=0.04\right)$ whereas it is significant with the silt fraction $(>4 \mu \mathrm{m}$ and $<63 \mu \mathrm{m})\left(\mathrm{R}^{2}=0.51, \quad \mathrm{p}=3.10^{-7}\right)$. $[\mathrm{THg}]_{\text {sed }}$ in sediments from the pristine area vary linearly with the organic carbon $(O C)$ content $\left(\mathrm{p}<2.10^{-8}, \mathrm{R}^{2}=0.73\right.$, Fig. $4 \mathrm{a}$ ). Indeed, mainly metals present a high affinity for OM and clay due to their large specific surface area, high cation exchange capacity and negative surface charge (Horowitz, 1991). Low MeHg/THg ratios $(<1 \%)$ were generally reported for freshwater sediments (Hines et al., 2000; Liu et al., 2011; Ullrich et al., 2007; Zelewski et al., 2001 ) in accordance with $\mathrm{MeHg} / \mathrm{THg}$ ratio in the present study ranging from $0.1 \%$ to $1.15 \%$ with an average of $0.43 \pm 0.22 \%$. Methyl$\mathrm{Hg}$ and $\mathrm{THg}$ in sediments samples from pristine area are linked by a moderate but significant linear relationship $\left(R^{2}=0.52, p=3.10^{-5}\right.$, Fig. 4c). The linear relation between $[\mathrm{MeHg}]$ and $\mathrm{OC}$ content for all samples is of higher significance (Fig. $4 \mathrm{~b}, \mathrm{R}^{2}=0.72, \mathrm{p}=2.10^{-11}$ ), suggesting that the proportion of $\mathrm{OC}$ in sediments is the best single predictor for [ $\mathrm{MeHg}$ ] with $72 \%$ of its variation explained. $\mathrm{OM}$ is linked to $[\mathrm{MeHg}$ ] in sediments through its action on various methylation parameters like redox potential, electron donors for sulfate-reducing bacteria, or complexing agents for $\mathrm{Hg}$ compound (Schartup et al., 2013).

\subsection{Origin and fate of $\mathrm{Hg}$ released into rivers by ASGM}

"Anthropogenic Hg" is defined here as any form of $\mathrm{Hg}$ resulting from ASGM inputs. Both particulate and dissolved [THg] in surface waters were significantly higher in the active mining creeks than in the pristine area. The maximum value of $[\mathrm{THg}]_{\mathrm{P}}$ of $17.3 \mathrm{ng} . \mathrm{L}^{-1}$ in water is observed in the Chien creek, an active mined stream which was exploited during the night before sampling (conductivity of $130 \mu \mathrm{S} \mathrm{cm}^{-1}$ early in the morning). This high [THg] $]_{\mathrm{P}}$ was associated with a moderate value of $[\mathrm{THg}]_{\mathrm{D}}\left(0.68 \mathrm{ng} . \mathrm{L}^{-1}\right)$. The two other samples coming from active mined creeks (but not exploited in the night before the sampling) present low $[\mathrm{THg}]_{\mathrm{P}}$ and moderate $[\mathrm{THg}]_{\mathrm{D}}$ when compared to other freshwaters sampled in the goldmining area. This indicates that the impact of gold-mining activities on $[\mathrm{THg}]_{\mathrm{D}}$ in surface water is moderate $(+38 \%$ when compared to pristine area) but homogeneous at the basin scale. Conversely, the impact of gold-mining on $[\mathrm{THg}]_{\mathrm{P}}$ in water is higher in the few hours following gold extraction (up to 7 times higher than in the pristine area), but heterogeneous at the basin scale (RSD in the
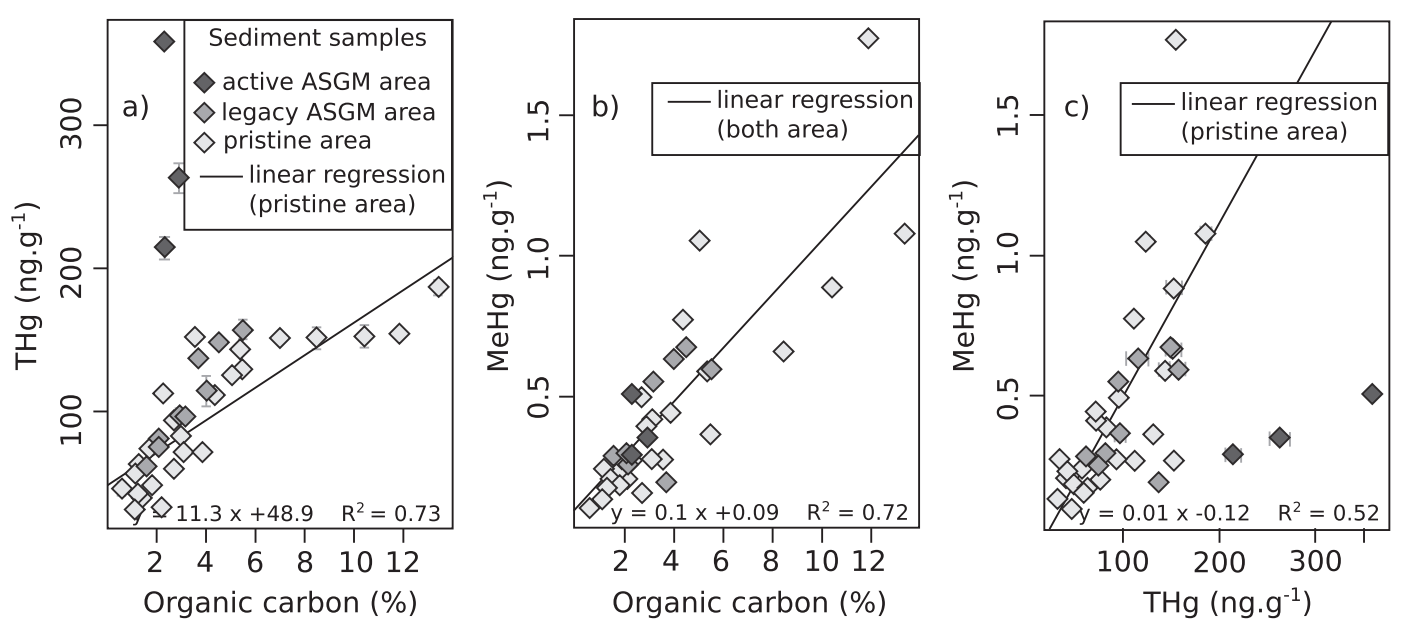

Fig. 4. Relations between THg, MeHg and Organic Carbon in sediment samples. 
mining area: 113\%). Nriagu (1993) studied Hg partitioning between dissolved and particulate forms in the gold-mined Madeira River, and showed that dissolved $\mathrm{Hg}$ concentrations are independent of [THg] in suspended matter, contrarily to pristine areas of the Amazon basin (Maia et al., 2009). Dissolved organic matter (DOM) interacts strongly with $\mathrm{Hg}$, through a strong binding between DOM and $\mathrm{Hg}$ and the ability of DOM to enhance the dissolution of $\mathrm{Hg}$ (Ravichandran, 2004). In the present study, the relationships existing between dissolved $\mathrm{OC}$ and $[\mathrm{THg}]_{\mathrm{D}}\left(\mathrm{R}^{2}=0.38, \mathrm{p}=0.025\right)$ and the low concentrations of $[\mathrm{THg}]_{\mathrm{D}}$ in active mined creeks confirmed that anthropogenic $\mathrm{Hg}$, mostly bound to particles, is weakly dissolved in creeks and rivers.

The three sediment samples from actively mined creeks have a different pattern from other sediment samples concerning $\mathrm{THg}$, $\mathrm{MeHg}$ and $\mathrm{OC}$ relationships. These 3 samples display the highest $[\mathrm{THg}]_{\text {sed }}$ (ranging from 214 to $358 \mathrm{ng} \mathrm{g}^{-1}$ ) and do not fit the linear relation between $\mathrm{MeHg}$ and $\mathrm{THg}$ in pristine sediments described in $\S 3.2$ (Fig. 4c) whereas the other samples coming from mining area do. This suggests that the THg in sediments from active mined sites is a combination of several $\mathrm{Hg}$ species, with at least one of them having a different potential for methylation than the natural $\mathrm{Hg}$ contributing to pristine sediments. The three sediment samples coming from active mined creeks are the only data that do not follow the relationships between $[\mathrm{THg}]$ and $\mathrm{OC}$ content observed in all other sediments (Fig. 4a). Therefore i) in pristine sediments, $\mathrm{THg}$ is significantly correlated with $O C$ content and silt fraction, reflecting that the erosion process of naturally Hg-enriched soils is the main source of $\mathrm{THg}$ in river sediments, ii) in the active ASGM sediments, THg is not correlated with OC content suggesting an additional source of $\mathrm{Hg}$ and iii) in the legacy ASGM area, $\mathrm{THg}$ in sediments follow the same correlation curve with OC than this of pristine river sediments, suggesting that the supposed past anthropogenic $\mathrm{THg}$ has probably been exported downstream with floods according to the sediment dynamics (Maurice, 2001).

There are two main pathways for anthropogenic $\mathrm{Hg}$ input from gold-mining sites to the hydrosystem: intensive erosion of naturally $\mathrm{Hg}$-rich soils during gold-mining activities through deforestation and direct release of liquid $\mathrm{Hg}$ after amalgamation.

We hypothesize that the anthropogenic THg measured in the active mined sediment samples is associated with the direct release of liquid $\mathrm{Hg}$ in the environment during gold-mining amalgamation. After the release of liquid $\mathrm{Hg}$ into soils, it can be transferred to sediments, and later oxidized to $\mathrm{Hg}^{\text {II }}$ forms. However, as long as it stays in the $\mathrm{Hg}(0)$ form it cannot be directly methylated. Previously, it has been shown that main part of elemental $\mathrm{Hg}$ released from gold-mining activities stays in its elemental form in sediment: in batch experiment, when droplets of $\mathrm{Hg}$ are introduced in microcosms with water and no sediments, $\mathrm{Hg}(0)$ is oxidized and methylated in the column water (Dominique et al., 2007). When the droplets are introduced in microcosms with water and sediments, $\mathrm{Hg}$ droplets are trapped and stabilized in sediments, limiting dissolution and oxidation process. In the same way, Pfeiffer et al. (1993) proposed that in the highly contaminated Madeira River sediments, $70-95 \%$ of the $\mathrm{THg}$ is present as elemental $\mathrm{Hg}(0)$. Reuther (1994) also explained that an essential part of the released metallic $\mathrm{Hg}$ still exists as distinct macroscopic liquid $\mathrm{Hg}(0)$ drops in the sediment. These studies support the binary mixing (Fig. 2, $\mathrm{R}^{2}=0.82, \mathrm{p}=2.10^{-15}$ ) between 2 end-members: sediments from the pristine area (Trois Sauts) and liquid mercury used by goldminers in French Guiana.

In active mined sediment rivers or creeks, we cannot exclude the occurrence of naturally $\mathrm{Hg}$-rich soil particles coming from intensive erosion during mining activities. In active mined sediments, the isotopic signature of $\mathrm{THg}$ would be similar to those of pristine sediments or pristine soils; as observed by Adler
Miserendino et al. (2017) downstream of the ASGM sites, the Hg isotope data is consistent with elevated $\mathrm{Hg}$ coming dominantly from increased erosion of soils and not from $\mathrm{Hg}$ used during gold extraction. It is thus possible that the high $[\mathrm{THg}]_{\text {sed }}$ in the active mined sediments results from a mix between liquid $\mathrm{Hg}$ input and an excess of Hg-rich soil particles. We have investigated this hypothesis using a double modelling approach described in the following part

\subsection{Anthropogenic Hg sources in Oyapock R. basin sediments simulated by coupled modelling}

We developed two different but complementary models: 1) a multiple linear regression (MLR) to estimate the part of anthropogenic $\mathrm{Hg}$, ie any form of $\mathrm{Hg}$ resulting from ASGM inputs, and 2) a binary mixing model to discriminate only the part of liquid $\mathrm{Hg}$ used by gold miners, in the $\mathrm{THg}$ concentrations measured in river sediments.

\subsubsection{Discrimination of anthropogenic $\mathrm{Hg}$ in sediments by multiple linear regression}

Anthropogenic $\mathrm{Hg}$ was quantified using a multiple linear regression (MLR) model based on the $[\mathrm{THg}]_{\text {sed }}$ in the pristine area and various physico-chemical parameters as explanatory variables (sampling site, granulometry, $\mathrm{MeHg}$ and $\mathrm{OC}$ concentrations, $\mathrm{C} / \mathrm{N}$ ratios). An intermediate model, chosen after stepwise algorithm and manual analysis, explained $87 \%$ of pristine log ([THg]sed) variance with $\mathrm{OC}$ concentration and clay fraction. After analyzing the residuals, we decided to discard sample R12-06 which presented a Cook distance greater than 0.5 . This sediment was sampled in a very small creek $5 \mathrm{~km}$ upstream of the confluence with the Oyapock R. The final model explained $91 \%$ of the pristine $\log ([\mathrm{THg}]$ sed) variance based on the OC concentration and the clay fraction (contributing respectively to $71 \%$ and $20 \%$ of the total variance, table $1, \mathrm{R}^{2}=0.91$, residual standard error $=0.16, \mathrm{p}=2.10^{-12}$ ). Theoretical natural $\mathrm{THg}$ concentrations ([THg]th) in sediments from the mining area were then calculated using equation (3):

$\log [\mathrm{THg}]$ th $=3.19+0.13 \times \operatorname{Corg}+0.08 \times F<4 \mu \mathrm{m}$

where Corg is the OC content and $\mathrm{F}<4 \mu \mathrm{m}$ is the clay fraction (\%) of bulk sediment. The OC content of the sediment is a proxy for OM content, which is mainly found in the silt fraction. The significant correlation of [THg]sed with silts observed by a univariate analysis in section 3.2 was mainly explained by the OM content in this grain fraction. However, the LMR model evidenced two control factors of [THg]th in sediments: the OM content and the clay fraction (due to their specific area as confirmed by previous study (MauriceBourgoin et al. (2002)). The [THg]th of all mining sediments varied between 67 and $175 \mathrm{ng} \mathrm{g}^{-1}$ with a mean of $100 \pm 31 \mathrm{ng} \mathrm{g}^{-1}$ which is consistent with $[\mathrm{THg}]_{\text {sed }}$ measured in pristine sediments $\left(95 \pm 45 \mathrm{ng} \mathrm{g}^{-1}\right)$. The fraction of anthropogenic THg in sediments from mining area $\left(F_{a n t}\right)$ was calculated following equation (4):

$F_{\text {ant }}=\frac{[\mathrm{THg}]_{\text {sed }}-[\mathrm{THg}]_{\text {th }}}{[\mathrm{THg}]_{\text {sed }}}$

The fraction of anthropogenic $\mathrm{Hg}$ in sediments from the mining area ranged from $-36 \%$ to $+78 \%$ with an average of $20 \% \pm 32 \%$ with only one value significantly inferior to 0 and exhibiting the largest confidence interval. The three highest fractions of anthropogenic $\mathrm{Hg}(36 \%, 61 \%$ and $78 \%)$ were found in the three samples from active mined creeks and the maximum was found in sediment from the creek mined during the night before sampling. 


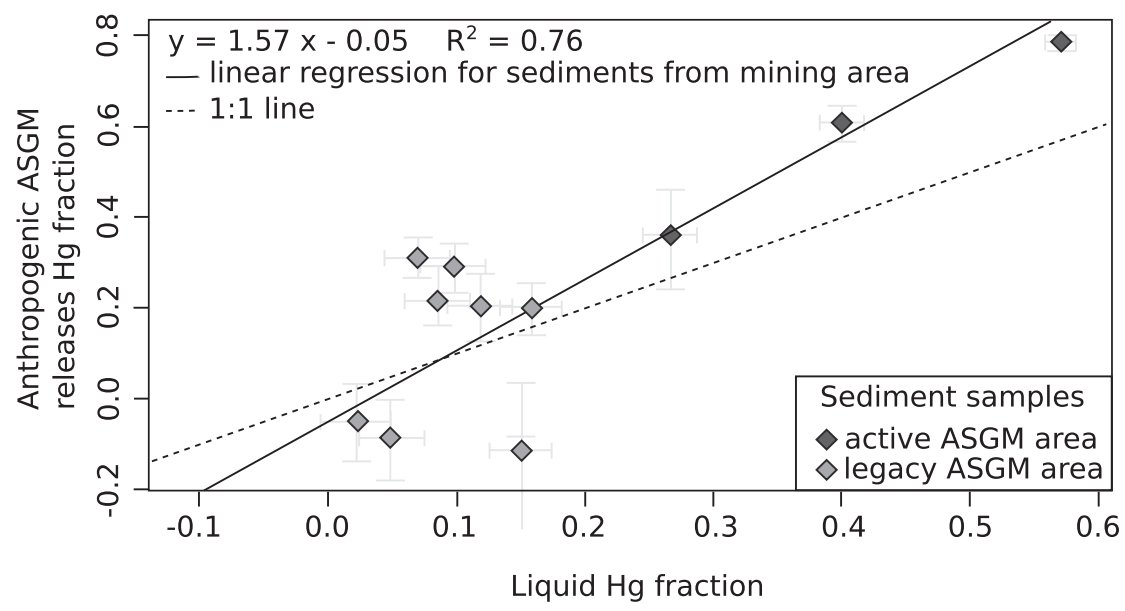

Fig. 5. Anthropogenic Hg fraction (calculated using MLR) vs liquid Hg fraction (calculated using isotopic Hg model) in sediments from mining area.

\subsubsection{Discrimination of liquid $\mathrm{Hg}$ input in sediments by a binary mixing model}

As all $\mathrm{Hg}$ stable isotope signatures of sediment samples from the mining area fall on a mixing line between the isotopic composition of two end-members, liquid $\mathrm{Hg}$ and pristine sediments (Fig. 2), it is possible to calculate the fraction of liquid mercury using a binary mixing model. The coefficients of variation of MDF and MIF in sediments from pristine area were very weak (5 and 6\%), reflecting the homogeneity of their $\mathrm{Hg}$ isotopic composition. We used two end-members for the linear regression, the MIF of local liquid $\mathrm{Hg}$ $\left(\Delta^{199} \mathrm{Hg}=-0.03 \pm 0.04, \mathrm{n}=5\right)$ and the MIF measured in pristine sediments i.e., the average for sediments from both Camopi and Oyapock river sampled upstream from gold-mining sites $\left(\Delta^{199} \mathrm{Hg}=-0.66 \pm 0.04 \%, \mathrm{n}=27\right)$. MIF was used instead of MDF as $\mathrm{Hg}$ origin tracer because of the MDF occurring during amalgamation whereas no MIF was noticed ${ }^{17}$. The fraction of liquid mercury $(f)$ was then calculated following equation (5):

$$
\Delta^{199} \mathrm{Hg}_{\text {sed }}=\Delta^{199} \mathrm{Hg}_{\text {liq }} * \mathrm{f}+\Delta^{199} \operatorname{Hg}_{\text {nat }} *(1-\mathrm{f})
$$

where $\Delta^{199}$ is the isotopic signature in the considered sediment $\left(\mathrm{Hg}_{\text {sed }}\right)$, in the liquid $\mathrm{Hg}$ from gold amalgamation $\left(\mathrm{Hg}_{\text {liq }}\right)$ and in the $\mathrm{Hg}$ accumulated in sediments from other sources $\left(\mathrm{Hg}_{\text {nat }}\right)$. The three samples coming from active mined creeks exhibit 27,38 and $56 \%$ of liquid mercury, with a maximum for the sediment coming from the creek mined during the night before the sampling. Other sediments from the legacy ASGM area showed an average fraction of liquid mercury of $7 \pm 7 \%$.

Assuming that the liquid $\mathrm{Hg}$ fraction is part of the anthropogenic $\mathrm{Hg}$ fraction discriminated by the MLR model (Fig. 5), the MLR results allowed us to estimate, that in the active mined sediments, the major part of anthropogenic $\mathrm{Hg}(66-74 \%)$ had the isotopic signature of liquid mercury whereas this proportion was lower in the legacy ASGM area. In the active mined sediments, $26-34 \%$ of the remaining anthropogenic $\mathrm{Hg}$ showed the same $\mathrm{Hg}$ MIF as this of pristine sediments (Fig. $2 ; \mathrm{R}^{2}=0.82, \mathrm{p}=2.10^{-15}$ ) and may originate from $\mathrm{Hg}$-rich soil erosion released to the hydrosystem during goldmining activities, or carried from upstream areas.

\section{Conclusion}

Mercury speciation and stable isotope fractionation study in French Guiana allowed us to quantify, for the first time, the impact of gold mining on the $\mathrm{Hg}$ contamination of rivers sediments. This original study combined two different models to discriminate the part of the anthropogenic $\mathrm{Hg}$ in bottom sediments of tropical rivers affected by ASGM and the part of liquid $\mathrm{Hg}$ used by gold-miners in the anthropogenic Hg sources. Previous recent studies just identified the fraction of liquid $\mathrm{Hg}$ in the total $\mathrm{Hg}$ content in bottom sediments. Thus, combining stable isotopes and geochemical analysis, a two-end members $\mathrm{Hg}$ MIF model and a multiple linear regression model, suggests that: i) recent gold mining activities impact the $\mathrm{Hg}$ content of bottom sediments in a proportion that can reach more than half of the total $\mathrm{Hg}$ concentration in the active mined sediments, ii) anthropogenic $\mathrm{Hg}$ was detected until the confluence of mined creeks with the mainstream rivers didn't affect significantly the larger Oyapock and Camopi Rivers downstream the confluence with gold-mined creeks (as it represents $3-16 \%$ of the total $\mathrm{Hg}$ content which is in the range of the analytical error) and iii) anthropogenic $\mathrm{Hg}$, mainly coming from liquid mercury release in aquatic system, and essentially sorbed on the clay fraction and the OM, is mobile and scatters quickly in the environment after deposition. Further study of fish contamination and human biomonitoring of $\mathrm{Hg}$ associated to the present project will be helpful to assess health risk to the local population related to fish consumption from the pristine and gold-mining areas.

\section{Acknowledgements}

This work was supported by the French National Research Agency (ANR-11-CESA-0013, RIMNES Program) and all the analyses were performed in two different laboratories of the Midi-Pyrénées Observatory (OMP-GET and ECOLAB). We would like to sincerely thank the local populations from Trois Sauts and Camopi villages for their kind cooperation during the field work, the fishermen for sharing their knowledge of the territory, and the Parc Amazonien de Guyane for the organization of the field trips along the Oyapock River. Back in France, we are pleased to acknowledge Frederic Julien, Adrien Bosq and Williams Limon for their help in granulometry and total mercury analysis. We thank the editor (Dr. Martine Leermakers) and the reviewers for their constructive advices and criticisms.

\section{Appendix A. Supplementary data}

Supplementary data to this article can be found online at https://doi.org/10.1016/j.chemosphere.2018.12.036. 


\section{References}

Adler Miserendino, R., Guimarães, J.R.D., Schudel, G., Ghosh, S., Godoy, J.M. Silbergeld, E.K., Lees, P.S.J., Bergquist, B.A., 2017. Mercury pollution in Amapa, Brazil: mercury amalgamation in artisanal and small-scale gold mining or landcover and land-use changes? ACS Earth Space Chem. 2, 441-450.

Amouroux, D., Wasserman, J.C., Tessier, E., Donard, O.F., 1999. Elemental mercury in the atmosphere of a tropical Amazonian forest (French Guiana). Environ. Sci. Technol. 33, 3044-3048.

Bergquist, B.A., Blum, J.D., 2009. The odds and evens of mercury isotopes: applications of mass-dependent and mass-independent isotope fractionation. Elements 5, 353-357.

Bergquist, B.A., Blum, J.D., 2007. Mass-dependent and-independent fractionation of $\mathrm{Hg}$ isotopes by photoreduction in aquatic systems. Science 318, 417-420.

Blum, J.D., Bergquist, B.A., 2007. Reporting of variations in the natural isotopic composition of mercury. Anal. Bioanal. Chem. 388, 353-359.

Blum, J.D., Sherman, L.S., Johnson, M.W., 2014. Mercury isotopes in earth and environmental sciences. Annu. Rev. Earth Planet Sci. 42, 249-269.

Castilhos, Z., Rodrigues-Filho, S., Cesar, R., Rodrigues, A.P., Villas-Bôas, R., de Jesus, I., Lima, M., Faial, K., Miranda, A., Brabo, E., et al., 2015. Human exposure and risk assessment associated with mercury contamination in artisanal gold mining areas in the Brazilian Amazon. Environ. Sci. Pollut. Res. 22, 11255-11264.

Chen, J., Hintelmann, H., Feng, X., Dimock, B., 2012. Unusual fractionation of both odd and even mercury isotopes in precipitation from Peterborough, ON, Canada. Geochim. Cosmochim. Acta 90, 33-46.

Deloitte Développement Durable, 2018. Le potentiel de développement économique durable de la Guyane. Deloitte Conseils Report, 523 pages, Nov. 2018.

Demers, J.D., Blum, J.D., Zak, D.R., 2013. Mercury isotopes in a forested ecosystem: implications for air-surface exchange dynamics and the global mercury cycle. Glob. Biogeochem. Cycles 27, 222-238.

Demers, J.D., Sherman, L.S., Blum, J.D., Marsik, F.J., Dvonch, J.T., 2015. Coupling atmospheric mercury isotope ratios and meteorology to identify sources of mercury impacting a coastal urban-industrial region near Pensacola, Florida, USA. Glob. Biogeochem. Cycles 29, 1689-1705. https://doi.org/10.1002 2015 GB005146.

Dominique, Y., Muresan, B., Duran, R., Richard, S., Boudou, A., 2007. Simulation of the chemical fate and bioavailability of liquid elemental mercury drops from gold mining in Amazonian freshwater systems. Environ. Sci. Technol. 41, 7322-7329.

Donovan, P.M., Blum, J.D., Bliss Singer, M., Marvin-DiPasquale, M., Tsui, M.T.K., 2016. Isotopic composition of inorganic mercury and methylmercury downstream of a historical gold mining region. Environ. Sci. Technol. 50, 1691-1702.

Enrico, M., Le Roux, G., Heimbürger, L.-E., Van Beek, P., Souhaut, M., Chmeleff, J., Sonke, J.E., 2017. Holocene atmospheric mercury levels reconstructed from peat bog mercury stable isotopes. Environ. Sci. Technol. 51, 5899-5906.

Enrico, M., Le Roux, G., Marusczak, N., Heimbürger, L.-E., Claustres, A., Fu, X., Sun, R., Sonke, J.E., 2016. Atmospheric mercury transfer to peat bogs dominated by gaseous elemental mercury dry deposition. Environ. Sci. Technol. 50, 2405-2412.

Gray, J.E., Pribil, M.J., Van Metre, P.C., Borrok, D.M., Thapalia, A., 2013. Identification of contamination in a lake sediment core using $\mathrm{Hg}$ and $\mathrm{Pb}$ isotopic compositions, Lake Ballinger, Washington, USA. Appl. Geochem. 29, 1-12.

Grimaldi, M., Gaudet, J., Grimaldi, C., Melieres, M., Spadini, L., 2001. Sources, Budget and Transfers in Soils and Sediments. Mercury Fr. Guiana Res. Program Final Rep. Part One Reg. St. Elie Petit Saut Reserv. CNRS-PEVS 5-15.

Guedron, S., Grimaldi, C., Chauvel, C., Spadini, L., Grimaldi, M., 2006. Weathering versus atmospheric contributions to mercury concentrations in French Guiana soils. Appl. Geochem. 21, 2010-2022.

Harada, M., Nakanishi, J., Yasoda, E., Maria da Conceicâo, N.P., Oikawa, T, de Assis Guimarâes, G., da silva Cardoso, B., Kizaki, T., Ohno, H., 2001. Mercury pollution in the Tapajos River basin, Amazon: mercury level of head hair and health effects. Environ. Int. 27, 285-290.

Heimbürger, L.-E., Sonke, J.E., Cossa, D., Point, D., Lagane, C., Laffont, L., Galfond, B.T Nicolaus, M., Rabe, B., Van Der Loeff, M.R., 2015. Shallow methylmercury production in the marginal sea ice zone of the central Arctic Ocean. Sci. Rep. 5 10318.

Hiez, G., Dubreuil, P., 1963. Les régimes hydrologiques en Guyane française. ORS TOM Editions.

Hines, M.E., Horvat, M., Faganeli, J., Bonzongo, J.-C.J., Barkay, T., Major, E.B., Scott, K.J. Bailey, E.A., Warwick, J.J., Lyons, W.B., 2000. Mercury biogeochemistry in the idrija river, Slovenia, from above the mine into the gulf of Trieste. Environ. Res. 83, 129-139.

Horowitz, A.J., 1991. Primer on Sediment-trace Element Chemistry. USGS.

Jiskra, M., Wiederhold, J.G., Skyllberg, U., Kronberg, R.-M., Hajdas, I., Kretzschmar, R., 2015. Mercury deposition and re-emission pathways in boreal forest soils investigated with Hg isotope signatures. Environ. Sci. Technol. 49, 7188-7196.

Jiskra, M., Wiederhold, J.G., Skyllberg, U., Kronberg, R.-M., Kretzschmar, R., 2017. Source tracing of natural organic matter bound mercury in boreal forest runoff with mercury stable isotopes. Environ. Sci. Process Impact. 19, 1235-1248.

Lacerda, L.D., 2003. Updating global Hg emissions from small-scale gold mining and assessing its environmental impacts. Environ. Geol. 43, 308-314.

Lacerda, L.D. de, Salomons, W., 2012. Mercury from Gold and Silver Mining: a Chemical Time Bomb? Springer Science \& Business Media.
Laffont, L., Sonke, J.E., Maurice, L., Monrroy, S.L., Chincheros, J., Amouroux, D., Behra, P., 2011. Hg speciation and stable isotope signatures in human hair as a tracer for dietary and occupational exposure to mercury. Environ. Sci. Technol. 45, 9910-9916.

Laperche, V., Hellal, J., Maury-Brachet, R., Joseph, B., Laporte, P., Breeze, D., Blanchard, F., 2014. Regional distribution of mercury in sediments of the main rivers of French Guiana (Amazonian basin). SpringerPlus 3, 322.

Legg, E.D., Ouboter, P.E., Wright, M.A.P., 2015. Small-scale Gold Mining Related Mercury Contamination in the Guianas: a Review. WWF Guiana.

Liu, J., Feng, X., Yin, R., Zhu, W., Li, Z., 2011. Mercury distributions and mercury isotope signatures in sediments of Dongjiang, the Pearl River Delta, China. Chem. Geol. 287. https://doi.org/10.1016/j.chemgeo.2011.06.001.

Maia, P.D., Maurice, L., Tessier, E., Amouroux, D., Cossa, D., Pérez, M., MoreiraTurcq, P., Rhéault, I., 2009. Mercury distribution and exchanges between the Amazon River and connected floodplain lakes. Sci. Total Environ. 407, 6073-6084. https://doi.org/10.1016/j.scitotenv.2009.08.015.

Martın-Doimeadios, R.C.R., Tessier, E., Amouroux, D., Guyoneaud, R., Duran, R., Caumette, P., Donard, O.F.X., 2004. Mercury methylation/demethylation and volatilization pathways in estuarine sediment slurries using species-specific enriched stable isotopes. Mar. Chem. 90, 107-123.

Masbou, J., Point, D., Sonke, J.E., Frappart, F., Perrot, V., Amouroux, D., Richard, P., Becker, P.R., 2015. Hg stable isotope time Trend in ringed seals registers decreasing sea ice cover in the Alaskan Arctic. Environ. Sci. Technol. 49, 8977-8985. https://doi.org/10.1021/es5048446.

Mason, R.P., Fitzgerald, W.F., Morel, F.F.M., 1994. The biogeochemical cycling of elemental mercury: anthropogenic influences. Geochem. Cosmochim. Acta 58 (15), 3191-3198.

Maurice, L., 2001. Le mercure dans les eaux de surface du bassin amazonien: transfert du mercure des sols aux milieux aquatiques, spéciation, transport et sédimentation dans les rivières et plaines d'inondation. In: Le Mercure En Amazonie: Rôle de l'homme et de l'environnement, Risques Sanitaires. IRD Editions, pp. 167-201.

Maurice-Bourgoin, L., Aalto, R., Guyot, J.L., 2002. Sediment associated mercury distribution within a major Amazon tributary: century-scale contamination history and importance of flood plain accumulation. In: Dyer, F.J., Thoms, M.C., Olley, J.M. (Eds.), The Structure, Funtion and Management Implications of Fluvial Sedimentary Systems: International Symposium, Alice Springs, Australia. International Association of Hydrological Sciences: Alice Springs, Australia, pp. 161-168.

Maurice-Bourgoin, L., Quemerais, B., Moreira-Turcq, P., Patrick, S., 2003. Transport, distribution and speciation of mercury in the Amazon River at the confluence of black and white waters of the Negro and Solimoes rivers. Hydrol. Process. 17, 1405-1417.

Maurice-Bourgoin, L., Quiroga, I., Chincheros, J., Courau, P., 2000. Mercury distribution in waters and fishes of the upper Madeira rivers and mercury exposure in riparian Amazonian populations. Sci. Total Environ. 260, 73-86.

Monperrus, M., Gonzalez, P.R., Amouroux, D., Alonso, J.I.G., Donard, O.F.X., 2008. Evaluating the potential and limitations of double-spiking species-specific isotope dilution analysis for the Accurate quantification of mercury species in different environmental matrices. Anal. Bioanal. Chem. 390, 655-666.

Morel, F.M.M., Kraepiel, A.M.L., Amyot, M., 1998. The chemical cycle and bioaccumulation of mercury. Annu. Rev. Ecol. Syst. 29, 543-566.

Niane, B., Guedron, S., Moritz, R., Cosio, C., Ngom, P.M., Deverajan, N., Pfeifer, H.R., Pote, J., 2015. Human exposure to mercury in artisanal small-scale gold mining areas of Kedougou region, Senegal, as a function of occupational activity and fish consumption. Environ. Sci. Pollut. Res. 22.

Nriagu, J.O., 1993. Mercury Pollution from Silver Mining in Colonial South America. National Water Research Institute.

Obrist, D., Kirk, J.L., Zhang, L., Sunderland, E.M., Jiskra, M., Selin, N.E., 2018. A review of global environmental mercury processes in response to human and natural perturbations: changes of emissions, climate, and land use. Ambio 47, 116-140.

Perrot, V., Epov, V.N., Pastukhov, M.V., Grebenshchikova, V.I., Zouiten, C., Sonke, J.E. Husted, S., Donard, O.F.X., Amouroux, D., 2010. Tracing sources and bioaccumulation of mercury in fish of lake Baikal, Angara river using $\mathrm{Hg}$ isotopic composition. Environ. Sci. Technol. 44.

Pfeiffer, W.C., Lacerda, L.D., Salomons, W., Malm, O., 1993. Environmental fate of mercury from gold mining in the Brazilian Amazon. Environ. Rev. 1, 26-37. https://doi.org/10.1139/a93-004.

Rahm, M., Thibault, P., Shapiro, A., Smartt, T., Paloeng, C., Crabbe, S., Farias, P. Carvalho, R., Joubert, P., 2017. Monitoring the Impact of Gold Mining on the Forest Cover and Freshwater in the Guiana Shield. WWF and ONFInt, p. 20. Reference year 2015.

Ravichandran, M., 2004. Interactions between mercury and dissolved organic matter--a review. Chemosphere 55, 319-331. https://doi.org/10.1016/j. chemosphere.2003.11.011.

Reuther, R., 1994. Mercury accumulation in sediment and fish from rivers affected by alluvial gold mining in the Brazilian Madeira River basin, Amazon. Environ. Monit. Assess. 32, 239-258. https://doi.org/10.1007/BF00546279.

Roulet, M., Grimaldi, C., 2001. Le mercure dans les sols d'Amazonie: origine et comportement du mercure dans les couvertures ferrallitiques du bassin amazonien et des Guyanes. In: Le Mercure En Amazonie: Rôle de l'homme et de l'environnement, Risques Sanitaires. IRD Editions, pp. 121-165.

Roulet, M., Lucotte, M., Canuel, R., Rheault, I., Tran, S., Gog, Y.D.F.,, et al., 1998a. Distribution and partition of total mercury in waters of the Tapajos river basin, Brazilian Amazon. Sci. Total Environ. 213, 203-211. 
Roulet, M., Lucotte, M., Farella, N., Serique, G., Coelho, H., Sousa Passos, C.J., de Jesus da Silva, E., Scavone de Andrade, P., Mergler, D., Guimarães, J.R.D., Amorim, M., 1999. Effects of recent human colonization on the presence of mercury in Amazonian ecosystems. Water, Air, Soil Pollut. 112 (3-4), 297-313.

Roulet, M., Lucotte, M., Rheault, I., Guimaraes, J.R., 2000. Methylmercury in water seston and epiphyton of an Amazonian river and its floodplain, Tapajos river Brazil. Sci. Total Environ. 261, 43-59.

Roulet, M., Lucotte, M., Saint-Aubin, A., Tran, S., Rheault, I., Farella, N.,, et al., 1998b. The geochemistry of mercury in central Amazonian soils developed on the Alter-do-Chao formation of the lower Tapajos River Valley, Para state, Brazil. Sci. Total Environ. 223, 1-24.

Schartup, A.T., Mason, R.P., Balcom, P.H., Hollweg, T.A., Chen, C.Y., 2013. Methylmercury production in estuarine sediments: role of organic matter. Environ. Sci. Technol. 47, 695-700. https://doi.org/10.1021/es302566w.

Schudel, G., Adler Miserendino, R., Veiga, M.M., Velásquez-López, P.C., Lees, P.S.J. Winland-Gaetz, S., Guimarães, J.R.D., Bergquist, B.A., 2018. An investigation of mercury sources in the Puyango-Tumbes River: using stable $\mathrm{Hg}$ isotopes to characterize transboundary $\mathrm{Hg}$ pollution. Chemosphere 202, 777-787.

Schuster, E., 1991. The behavior of mercury in the soil with special emphasis on complexation and Adsorption processes - a review of the literature. Water Air Soil Pollut. 56, 667-680.

Sherman, L.S., Blum, J.D., 2013. Mercury stable isotopes in sediments and largemouth bass from Florida lakes, USA. Sci. Total Environ. Atmospheric Mercury Air Pollut. Assoc. Eff. Health Festschr. 448, 163-175. Profr. Jerry Keeler.

Sherman, L.S., Blum, J.D., Keeler, G.J., Demers, J.D., Dvonch, J.T., 2012. Investigation of local mercury deposition from a coal-fired power plant using mercury isotopes. Environ. Sci. Technol. 46, 382-390.

Sonke, J., 2011. A global model of mass independent mercury stable isotope fractionation. Geochim. Cosmochim. Acta 75, 4577-4590.

Telmer, K.H., Veiga, M.M., 2009. World emissions of mercury from artisanal and small scale gold mining. In: Pirrone, N., Mason, R., @Springer Science (Eds.), Mercury, Fate and Transport in the Global Atmosphere, pp. 131-172.

Ullrich, S.M., Ilyushchenko, M.A., Uskov, G.A., Tanton, T.W., 2007. Mercury distribution and transport in a contaminated river system in Kazakhstan and associated impacts on aquatic biota. Appl. Geochem. Biogeochem. Gradients Microbes Meas. Model. 22, 2706-2734.
UNEP, 2013. Global Mercury Assessment: Sources, Emissions, Releases and Environmental Transport. United Nations Environment Programme.

US EPA, 2002. Method 1631 Mercury in Water by Oxidation, Purge and Trap, and Cold Vapor Atomic Fluorescence Spectrometry.

Velásquez-López, P.C., 2010. Mercury in Artisanal and Small Scale Gold Mining : Identifying Strategies to Reduce Environmental Contamination in Southern Ecuador (PhD Thesis). University of British Columbia. https://doi.org/10.14288/ 1.0071256 .

Voicu, G., Bardoux, M. Stevenson, R., 2001. Lithostratigraphy, geochronology and gold metallogeny in the northern Guiana Shield, South America: a review. Ore Geol. Rev. 18, 211-236.

Wiederhold, J.G., 2015. Metal stable isotope signatures as tracers in environmental geochemistry. Environ. Sci. Technol. 49, 2606-2624.

Yin, R., Feng, X., Wang, J., Li, P., Liu, J., Zhang, Y., Chen, J., Zheng, L., Hu, T., 2013. Mercury speciation and mercury isotope fractionation during ore roasting process and their implication to source identification of downstream sediment in the Wanshan mercury mining area, SW China. Chem. Geol. 336, 72-79.

Yin, R., Feng, X., Li, X., Yu, B., Du, B., 2014. Trends and advances in mercury stable isotopes as a geochemical tracer. Trends Environ. Anal. Chem. 2, 1-10.

Yu, B., Fu, X., Yin, R., Zhang, H., Wang, X., Lin, C.-J., Wu, C., Zhang, Y., He, N., Fu, P. Wang, Z., Shang, L., Sommar, J., Sonke, J.E., Maurice, L., Guinot, B., Feng, X., 2016 Isotopic composition of atmospheric mercury in China: new evidence for sources and Transformation processes in air and in vegetation. Environ. Sci. Technol. 50, 9262-9269. https://doi.org/10.1021/acs.est.6b01782.

Zelewski, L.M., Benoit, G., Armstrong, D.E., 2001. Mercury dynamics in Tivoli south bay, a freshwater Tidal mudflat wetland in the hudson river. Biogeochemistry 52, 93-112.

Zhang, H., Yin, R.S., Feng, X.B., Sommar, J., Anderson, C.W., Sapkota, A.,, et al., 2013. Atmospheric mercury inputs in montane soils increase with elevation: evidence from mercury isotope signatures. Sci. Rep. 3, 3322.

Zheng, W., Hintelmann, H., 2010. Nuclear field shift effect in isotope fractionation of mercury during abiotic reduction in the absence of light. J. Phys. Chem. 114 (12) 4238-4245.

Zheng W., Obrist, D., Weis, D., Bergquist, B.A. 2016. Mercury isotope composition across North American forests. Glob. Biogeochem. Cycles 30, 1475-1492. https://doi.org/10.1002/2015GB005323. 